\title{
Impact of groundwater contamination on human health
}

\author{
D. Karunanidhi $\mathbb{D} \cdot$ T. Subramani $\cdot$ Priyadarsi D. Roy $\cdot$ Hui Li
}

Published online: 24 January 2021

(C) The Author(s), under exclusive licence to Springer Nature B.V. part of Springer Nature 2021

\section{Background}

Groundwater pollution is a worldwide problem with significant effects on human health and environmental security. It requires an in-depth understanding as the access to safe drinking water is a fundamental human right. The inferior quality of potable water has been deteriorating the human health and affecting the sustainable development of society. Increased urbanization and population growth in many parts of the world have exacerbated contamination of groundwater, mainly through the misuse of groundwater assets and the discharge of domestic and industrial sewage into the groundwater system. Human health is susceptible to the exposure of metal/metalloid, even at

D. Karunanidhi $(\square)$

Department of Civil Engineering, Sri Shakthi Institute of Engineering and Technology (Autonomous),

Coimbatore 641062, India

e-mail: karunasamygis@gmail.com

T. Subramani

Department of Geology, College of Engineering Guindy

(CEG), Anna University, Chennai 600025, India

P. D. Roy

Instituto de Geología, Universidad Nacional Autónoma de México (UNAM), Ciudad Universitaria,

04510 Ciudad de México, C.P, Mexico

H. Li

Department of Ecology, College of Life Science and

Technology, Jinan University, Guangzhou, China trace level, because of its persistence in the environmental media and acute toxicity.

This special issue "Impact of Groundwater Contamination on Human Health" is a compilation of new case studies about recent advances in ground-breaking research about groundwater characteristics and groundwater modelling in different parts of the world using multidisciplinary tools to evaluate the risk on human health as well as on agricultural activities from chemical compositions and radioactivity along with other cutting edge topics like waste water management as well as microbial and heavy metal contaminations. It contains 23 different research papers from five countries (China, India, Kazakhstan, Kuwait, and Malaysia) focussing on seven different topics: (1) Hydrogeochemistry, (2) Groundwater modelling, (3) Risk assessment, (4) Radioactivity, (5) Wastewater treatment, (6) Heavy metals contamination, and (7) Microbial contamination. This editorial briefly reviewed the papers that focussed on different topics of groundwater evaluation and characterization.

\section{Hydrogeochemistry}

Six papers of this topic represent case studies of saline water intrusion along the coastal Tamil Nadu and Puducherry states of south India using hydro-chemical and statistical techniques. Faizal Khan et al. (2020) reported about the mixing of seawater and 
groundwater in majority of the samples along the coastal south India. This study recommended implementation of proper awareness programs along with regular monitoring, regulated pumping from wells situated close to the coast and better agricultural practises in future. Satheeskumar et al. (2020) observed that more than $40 \%$ of samples in the Thamirabarani delta of south India are unsuitable for drinking, and their higher electrical conductivity (EC) and total dissolved solids (TDSs) values reflected the seawater intrusion, in addition to the anthropogenic activities (salt panning). Vinnarasi et al. (2020) assessed chemical weathering and atmospheric carbon dioxide $\left(\mathrm{CO}_{2}\right)$ in Shanmuganadhi River basin of south India in order to evaluate the groundwater quality management for decision-making.

Keesari and Dauji (2020) investigated groundwater salinization using correlation plots of $\mathrm{Na}+/ \mathrm{Cl}-$ versus Cl-. This study used qualitative and quantitative tools from published datasets. Marghade et al. (2019), however, used geochemical and multivariate statistical approaches to investigate groundwater quality and human health risk in a semi-arid region of Maharashtra state in western India. This study revealed water-rock interactions, de-dolomitization and reverse ion exchange as the main controlling processes. The health risks assessment from consumption of F-polluted groundwater showed more risk for children (40\%) compared to adults $(23 \%)$. The study also recommended rainwater harvesting for improving the groundwater quality as well as sustainable development and management of groundwater resources. The paper of Zhou et al. (2020) assessed the suitability of groundwater quality for irrigation and health risk in a part of north China and suggested that the deep groundwater is of better quality compared to shallow groundwater. Health risk evaluation indicated noncarcinogenic risk from $\mathrm{F}^{-}, \mathrm{Fe}$ and As. Regarding the deep groundwater, $\mathrm{Cr}^{6+}$ might contribute to nonnegligible non-carcinogenic risk for children.

\section{Groundwater modelling}

Three articles refer to this topic and the paper of Arya et al. (2019) evaluated health risk from rural drinking water supply by using inverse mass balance modelling (NETPATH code) in Vattamalaikarai River basin of south India. The calculated HQ values highlighted more risk for children and suggested effective remedial measures such as construction of artificial recharge structures to reduce the excess fluoride. Karunanidhi et al. (2020a, b) described subsurface hydrogeochemical processes in a geologically heterogeneous semi-arid region of south India using mass transfer and fuzzy comprehensive modelling, and reported high influence of silicate weathering, ion exchange and gypsum dissolution on overall quality of the groundwater. Similarly, Radelyuk et al. (2020) assessed groundwater safety close to contaminated water storage sites in Kazakhstan using multivariate statistical analysis and Heckman selection model (a very first attempt to evaluate environmental factors) and confirmed a high loading of anthropogenic contamination from the petrochemical industry coupled with natural geochemical processes.

\section{Risk assessment}

Out of the seven papers of this topic, Ahmed et al. (2020) evaluated the high carcinogenic and noncarcinogenic risk from arsenic (As) in drinking water in Langat River Basin of Malaysia. Even though the major source of As is changing landscape, examining ponds and extensive use of pesticides for palm oil plantation, this paper mentioned no potential noncarcinogenic health risk since the calculated hazard quotient (HQ) value was $<1$. He et al. (2020) discussed about the poor water quality in Datong Basin of northern China from high levels of arsenic (As), fluoride $\left(\mathrm{F}^{-}\right)$, and iodine (I). The long-term intake of this groundwater has led to endemic arsenicosis and fluorosis. This article recommended consumption of regular salt, and the conjunctive use of groundwater and surface water in the basin and mountainous areas as one of keys to sustainable health and groundwater management. In the Ordos Basin of China, Ding et al. (2020) assessed the agricultural and domestic challenges by focussing on the groundwater quality. The water quality of most samples is poor for consumption and $80 \%$ of the water, however, can be used for irrigation. Similarly, the children are exposed to higher risk compared to adults. Li et al. (2019) conducted an assessment of potential health risk of major contaminants in groundwater of Hebei Province in central China and reported non-carcinogenic risk values $(\mathrm{Rn})$ in the order infants $>$ children $>$ adult 
males $>$ adult females and the sequence of the carcinogenic risk values (Rc) in the order adult males $>$ adult females $>$ children $>$ infants.

Karunanidhi et al. (2020a) also discussed about drinking water quality and possible health risks in the Shanmuganadhi River Basin of south India. The water quality index (WQI) revealed that $52 \%$ of samples are in poor, very poor and not suitable categories, causing more health risk for children. In a study of southwestern Punjab (India), Kumar et al. (2020) described the source, distribution and potential health risk assessment. Elevated levels of $\mathrm{U}$ and $\mathrm{F}$ from the geogenic origin, along with the minor anthropogenic activities, are the major health risk pollutants. The carcinogenic health risk of As and $\mathrm{Cr}$ exceeded the USEPA limits $\left(10^{-6}\right)$ and this study recommended that the local government should take necessary steps to provide potable water facilities along with awareness camps. Subba Rao (2020) evaluated probabilistic noncarcinogenic risk in a rural dry area of south India with high nitrate (31-97 mg/L) and fluoride $(0.70-2.80 \mathrm{mg} / \mathrm{L})$ levels in groundwater. This research suggested adverse health risks among men, women, and children caused by sensitiveness to pollutants, and different body weights.

\section{Radioactivity}

Only one paper of this topic was by Nazir et al. (2020) and it investigated the dose estimation of radioactivity in groundwater from the Srinagar City (north India), using fluorometric and scintillation techniques to measure uranium and radon. The uranium concentration is less than the permissible limit $\left(30 \mu \mathrm{g} / \mathrm{L}^{-1}\right)$, but radon exceed the permissible limits of USEPA $(11 \mathrm{~Bq}$ $\mathrm{L}^{-1}$ ) in $32 \%$ of the samples. This interesting study found that areas with limestone lithology have a higher radon concentration.

\section{Wastewater treatment}

Out of the two paper of this topic, Sathya et al. (2020) investigated the utility of photochemical integrated submerged membrane bioreactor for textile dyeing wastewater treatment in SIPCOT, Perundurai (south India). The results showed that high removal efficiencies were achieved by integrating membrane with photocatalysis for the removal of various parameters (colour, COD, and TSS). About 78\% COD removal could be achieved by using this simple integrated system. Vasu et al. (2019) evaluated the degradation of simulated Direct Orange-S (DO-S) textile effluent by using nonthermal atmospheric pressure plasma jet. The paper suggested that the non-thermal plasma treatment is efficient as it induces the degradation of organic solutions.

\section{Microbial contamination}

The research paper of Vasudevan et al. (2020) carried out the evaluation of microbial contamination in shallow groundwater along the coastal Tamil Nadu (south India). It inferred more microbial activity in residential areas, cultivated regions and around the landfill sites due to the leaching of sewage water and fertilizer runoffs. The concentrations of ions and microbes remained above the permissible limits of drinking water, but was suitable for irrigation purpose.

\section{Heavy metals contamination}

In this topic, Ali and Chidambaram (2020) addressed the impact of $\mathrm{As}, \mathrm{Cd}, \mathrm{Ni}, \mathrm{Pb}$, and $\mathrm{V}$ on common fish varieties (Lobster and Speatty) along the Kuwait Bay. Effluents from oil-based industries, urban sewage, and wastewater drains (land-based effluents) and the redox conditions of the natural environment are identified as the chief sources of trace elements in the fish varieties. This paper suggests that the hazard impact was observed to be greater in female population than that in male. Similarly, Venkatesan et al. (2020) focussed on the chromium concentration in vegetables possibly inherited from the groundwater. This study recommended application of gypsum (calcium sulphate) during plouging of soil to improve the infiltration capacity of water by enhancing the soil structure and to raise salt-tolerant crops and practice crop rotation. In the water from Xiangxi River, and Three Gorges Reservoir of China, Xiong et al. (2020) studied spatial distribution of $\mathrm{Cu}, \mathrm{Cd}, \mathrm{Ni}$, and $\mathrm{Hg}$, originated primarily from agriculture, and the distributions of $\mathrm{Pb}, \mathrm{Zn}$, and As, originated from transportation and mining. The results of this study provided a reference to 
support prioritization and planning for heavy metals pollution control.

\section{Conclusion}

The subject of this special issue is of great importance for groundwater research, and the 23 papers covered different aspects of fundamental theoretical and applied research about groundwater contamination and human health in order to fill gaps in the existing knowledge.

Acknowledgements The successful editing of this special issue was not an easy task and the guest editors ensured that the topics were of broad interest to contributors without compromising the strict and efficient peer review process and the high quality evaluation. All of these would not have been achieved without the support and guidance of the Editor-inChief Prof. Ming Hung Wong. We are extremely grateful to Ms. Sherestha Saini, Managing Editor of EGAH, Ms. Sherine Joseph, Handling Editor, and Crystal Lin Siyi, Assistant to Prof. Wong. We are also sincerely thankful to all the reviewers for their time spent during the peer review and for helping to maintain the high standard of this special issue. Last but not the least, the authors whose manuscripts were included and those whose manuscripts were rejected, both contributed to the successful compilation of this special issue.

\section{References}

Ahmed, M. F., Mokhtar, M. B., \& Alam, L. (2020). Carcinogenic and non-carcinogenic health risk of arsenic ingestion via drinking water in Langat River Basin. Malaysia: Environ Geochem Health. https://doi.org/10.1007/s10653020-00571-w.

Ali, A., \& Chidambaram, S. (2020). Assessment of trace inorganic contaminates in water and sediment to address its impact on common fish varieties along Kuwait Bay. Environmental Geochemistry and Health. https://doi.org/10. 1007/s10653-020-00559-6.

Arya, S., Subramani, T., Vennila, G., \& Karunanidhi, D. (2019). Health risks associated with fluoride intake from rural drinking water supply and inverse mass balance modeling to decipher hydrogeochemical processes in Vattamalaikarai River basin. South India: Environmental Geochemistry and Health. https://doi.org/10.1007/s10653-01900489-y.

Ding, L., Yang, Q., Yang, Y., Ma, H., \& Martin, J. D. (2020). Potential risk assessment of groundwater to address the agricultural and domestic challenges in Ordos Basin. Environmental Geochemistry and Health. https://doi.org/10. 1007/s10653-019-00512-2.

He, X., Li, P., Wu, J., Wei, M., Ren, X., \& Wang, D. (2020). Poor groundwater quality and high potential health risks in the Datong Basin, northern China: Research from published data. Environmental Geochemistry and Health. https://doi.org/10.1007/s10653-020-00520-7.

Karunanidhi, D., Aravinthasamy, P., Deepali, M., Subramani, T., \& Sunkari, E. D. (2020a). Appraisal of subsurface hydrogeochemical processes in a geologically heterogeneous semi-arid region of south India based on mass transfer and fuzzy comprehensive modeling. Environmental Geochemistry and Health. https://doi.org/10.1007/ s10653-020-00676-2.

Karunanidhi, D., Aravinthasamy, P., Subramani, T., \& Muthusankar, G. (2020b). Revealing drinking water quality issues and possible health risks based on water quality index (WQI) method in the Shanmuganadhi River basin of South India. Environmental Geochemistry and Health. https:// doi.org/10.1007/s10653-020-00613-3.

Keesari, T., \& Dauji, S. (2020). Groundwater salinization processes: pitfalls of inferences from $\mathrm{Na}+/ \mathrm{Cl}-$ versus $\mathrm{Cl}-$ correlation plots. Environmental Geochemistry and Health. https://doi.org/10.1007/s10653-020-00622-2.

Khan, A. F., Srinivasamoorthy, K., Prakash, R., \& Rabina, C. (2020). Hydrochemical and statistical techniques to decode groundwater geochemical interactions and saline water intrusion along the coastal regions of Tamil Nadu and Puducherry. India: Environ Geochem Health. https:// doi.org/10.1007/s10653-020-00713-0.

Kumar, R., Mittal, S., Sahoo, P. K., \& Sahoo, S. K. (2020). Source apportionment, chemometric pattern recognition and health risk assessment of groundwater from southwestern Punjab. India: Environmental Geochemistry and Health. https://doi.org/10.1007/s10653-020-00518-1.

Li, Z., Yang, K., Xie, C., Yang, Q., Lei, X., \& Wang, H. (2019). Assessment of potential health risk of major contaminants of groundwater in a densely populated agricultural area. Environmental Geochemistry and Health. https://doi.org/ 10.1007/s10653-019-00470-9.

Marghade, D., Malpe, D. B., \& Subba Rao, N. (2019). Applications of geochemical and multivariate statistical approaches for the evaluation of groundwater quality and human health risks in a semi-arid region of eastern Maharashtra. India: Environmental Geochemistry and Health. https://doi.org/10.1007/s10653-019-00478-1.

Nazir, S., Simnani, S., Sahoo, B. K., Rashid, I., \& Masood, S. (2020). Dose estimation of radioactivity in groundwater of Srinagar City, Northwest Himalaya, employing fluorimetric and scintillation techniques. Environmental Geochemistry and Health. https://doi.org/10.1007/s10653-02000576-5.

Radelyuk, I., Tussupova, K., Persson, M., Zhapargazinova, K., \& Yelubay, M. (2020). Assessment of groundwater safety surrounding contaminated water storage sites using multivariate statistical analysis and Heckman selection model: A case study of Kazakhstan. Environmental Geochemistry and Health. https://doi.org/10.1007/s10653-020-00685-1.

Satheeskumar, V., Subramani, T., Lakshumanan, C., Roy, P. D., \& Karunanidhi, D. (2020). Groundwater chemistry and demarcation of seawater intrusion zones in the Thamirabarani delta of south India based on geochemical signatures. Environmental Geochemistry and Health. https://doi. org/10.1007/s10653-020-00536-z.

Sathya, U., Keerthi, P., Nithya, M., \& Balasubramanian, N. (2020). Development of photochemical integrated 
submerged membrane bioreactor for textile dyeing wastewater treatment. Environmental Geochemistry and Health. https://doi.org/10.1007/s10653-020-00570-x.

Subba Rao, N. (2020). Spatial distribution of quality of groundwater and probabilistic non-carcinogenic risk from a rural dry climatic region of South India. Environmental Geochemistry and Health. https://doi.org/10.1007/s10653020-00621-3.

Vasu, D., Navaneetha Pandiyaraj, K., Padmanabhan, P. V. A., Pichumani, M., Deshmukh, R. R., \& Jaganathan, S. K. (2019). Degradation of simulated direct orange-S (DO-S) textile effluent using nonthermal atmospheric pressure plasma jet. Environmental Geochemistry and Health. https://doi.org/10.1007/s10653-019-00446-9.

Vasudevan, U., Gantayat, R. R., Chidambaram, S., Prasanna, M. V., Venkatramanan, S., Devaraj, N., et al. (2020). Microbial contamination and its associations with major ions in shallow groundwater along coastal Tamil Nadu. Environ Geochem Health. https://doi.org/10.1007/s10653-02000712-1.

Venkatesan, G., Subramani, T., Sathya, U., \& Karunanidhi, D. (2020). Evaluation of chromium in vegetables and groundwater aptness for crops from an industrial (leather tanning) sector of South India. Environmental
Geochemistry and Health. https://doi.org/10.1007/s10653020-00665-5.

Vinnarasi, F., Srinivasamoorthy, K., Saravanan, K., Gopinath, S., Prakash, R., Ponnumani, G., \& Babu, C. (2020). Chemical weathering and atmospheric carbon dioxide (CO2) consumption in Shanmuganadhi, South India: Evidences from groundwater geochemistry. Environmental Geochemistry and Health. https://doi.org/10.1007/s10653020-00540-3.

Xiong, B., Li, R., Johnson, D., Luo, Y., Xi, Y., Ren, D., \& Huang, Y. (2020). Spatial distribution, risk assessment, and source identification of heavy metals in water from the Xiangxi River. Three Gorges Reservoir Region, China: Environmental Geochemistry and Health. https://doi.org/ 10.1007/s10653-020-00614-2.

Zhou, Y., Li, P., Chen, M., Dong, Z., \& Lu, C. (2020). Groundwater quality for potable and irrigation uses and associated health risk in southern part of Gu'an County. North China Plain: Environmental Geochemistry and Health. https://doi.org/10.1007/s10653-020-00553-y.

Publisher's Note Springer Nature remains neutral with regard to jurisdictional claims in published maps and institutional affiliations. 